\title{
Effects of Hypoxia on Stress Proteins in the Piglet Brain at Birth
}

\author{
MAGALI CHIRAL, JEAN-FRANÇOIS GRONGNET, JEAN-CHRISTOPHE PLUMIER, AND \\ JEAN CLAUDE DAVID
}

Agrocampus [M.C., J.-F.G., J.C.D.], 35042 Rennes Cedex, France; and Physiologie Animale [J.-C.P.], Département des Sciences de la Vie, Université de Liège, Belgium, and Stroke and Neurovascular Regulation, Harvard Medical School, Massachusetts General Hospital, Charlestown, MA 02129

\begin{abstract}
Newborn piglets were submitted to normobaric hypoxia $(5 \%$ $\mathrm{O}_{2}, 95 \% \mathrm{~N}_{2}$ ) for either 1 or $4 \mathrm{~h}$. The effects of hypoxia on the neonatal brain were characterized through a time-course analysis of levels of various proteins such as heat shock proteins (HSP27, 70 , and 90), hypoxia inducible factor- $1 \alpha$ (HIF- $1 \alpha)$, neuronal nitric oxide synthase (nNOS), hemeoxygenase-2 (HO-2), and caspase-3. The expression of these proteins was determined at different stages of recovery up to $72 \mathrm{~h}$ in cerebellum, cortex, and hippocampus by Western blot analysis in hypoxic maintained animals that were made hypoxic at either 20 or $37^{\circ} \mathrm{C}$. In all regions of the brain, HIF- $1 \alpha$ and HSP27 expression were strongly increased until $22 \mathrm{~h}$ of recovery. No significant changes were observed for HSP70, HSP90, and HO-2. A small elevation of expression of nNOS was observed at early stages in the cerebellum and the cortex with no change in the hippocampus.
\end{abstract}

\section{ABSTRACT}

Expression of caspase 3 was strongly increased in the cortex 24 and $48 \mathrm{~h}$ after hypoxia but unchanged in the hippocampus. These results are presented in terms of the porcine model of nonischemic hypoxia and its delayed neuronal effects on the cerebral outcome. Because of their recently established biochemical and functional interactions, the expression of the main HSPs, HIF$1 \alpha$, nNOS, and caspase-3 after hypoxia are delineated. (Pediatr Res 56: 775-782, 2004)
Abbreviations
HIF-1 $\alpha$, hypoxia inducible factor- $1 \alpha$
HO, hemooxygenase
HSP, heat shock protein
nNOS, neuronal nitric oxide synthase

Perinatal asphyxia and hypoxia are common causes of neonatal morbidity. Among survivors, several disabilities are observed, including pulmonary, renal, cardiac, and encephalopathic dysfunction $(1,2)$. Asphyxia at birth can result in severe auditory problems for the infant $(3,4)$ as well as increased risks of amnesia (5) and schizophrenia presenting at different stages (6). Outcomes of asphyxia and/or hypoxia-ischemia can also result in cognitive impairment and developmental delay for the infants (7). Such severe sequelae of birth hypoxia are apparent early at the molecular level in the brain. Impairment as a result of hypoxia includes the transient reduction of GABA receptor numbers (8), altered expression of glutamate transporters (9), and/or a disruption of myelin gene expression (10). Because of the severe consequences of hypoxia at birth time on cerebral functions, a better characterization of molecular changes within the hypoxic neonatal brain is of crucial importance.

Received April 7, 2003; accepted October 3, 2004.

Correspondence: Jean Claud David, Sciences et Productions Animales, Agrocampus, 65, rue de Saint-Brieuc, CS 84215, 35042 Rennes Cedex, France; e-mail: David@roazhon.inra.fr

We are grateful to the American Heart Association (grant 0265359T) for one of us (J.C.P.).

DOI: 10.1203/01.PDR.0000142732.09325.61
The study of the expression and induction of stress proteins in the hypoxic brain is of particular interest because heat shock proteins (HSPs) have cytoprotective properties and are induced after a variety of stressors, such as elevated temperature (11-13) or hypoxia (14). HSPs are classified in three large families according to their molecular weights (11-13). However, very few studies have described the developmental changes of HSPs at the time of birth (15-17). The protective role of HSPs against hypoxia at birth has not been investigated, although in the brain, these proteins are known to be cytoprotective after hypoxia-ischemia $(18,19)$. Other proteins induced by neonatal hypoxic stress are also of interest. Hypoxia inducible factor- $1 \alpha$ (HIF- $1 \alpha$ ) expression constitutes an early immediate response to oxygen deprivation (20-22) and triggers the induction of a number of downstream molecules $(23,24)$. Hypoxia induces a variety of proteins, including stress proteins. It has recently been established that HSP90 itself is closely associated with HIF-1 $\alpha$ (25) and other heme proteins, such as nitric oxide synthase (NOS) (26). NOS is reciprocally related to hemooxygenase-2 (HO-2), which by producing $\mathrm{CO}$ leads to opposing physiologic effects (27). Thus, a study of the effect 
of hypoxia on these factors in various subregions of the brain is important.

Our group has developed a neonatal piglet model that displays several similarities to the human infant, including alterations in response to hypoxia, such as changes in glutamate (28) or glucose transporters (29), and stress-related neurologic outcome (2). The aim of the present study was to determine the effect of birth hypoxia on stress proteins in the cerebellum, the cortex, and the hippocampus of piglets. Because HSP32 (HO2), HSP70, and HSP90 all interact with NOS and HSP90 interacts with HIF- $1 \alpha$, we specifically target these proteins.

\section{METHODS}

\section{Animals}

All experimental procedures were carried out in accordance with the French Ministry of Agriculture for the use and care of laboratory animals. Large white piglets were born at term and immediately placed in the hypoxia chamber. A total of 72 piglets were used. They were divided into three groups. Twenty-eight animals were chosen at random as controls, separated from their mothers, and housed at an ambient temperature of $20^{\circ} \mathrm{C}$ under normoxic conditions. Twenty-six animals were chosen at random and subjected to hypoxia at $20^{\circ} \mathrm{C}$ under a continuous flow of 5\% $\mathrm{O}_{2}$ and $95 \%$ of $\mathrm{N}_{2}$. Eighteen animals were chosen at random and subjected to hypoxia with their body temperature maintained at $37 \pm 1{ }^{\circ} \mathrm{C}$ throughout hypoxia by infrared heating lamps.

Oxygen saturation of venous $\mathrm{Hb}$ was measured by a hemoximeter (Type OSM-2; Radiometer Corp., Lyon, France) in blood obtained from the ear. The volume of the chamber was $214 \mathrm{~L}$. The complete renewal of the hypoxia chamber atmosphere occurred five times per hour. The animals were kept for $4 \mathrm{~h}, 1 \mathrm{~h}$, or as otherwise indicated. They were subsequently allowed to recover in ambient atmosphere and temperature for indicated periods. For experiments longer than $8 \mathrm{~h}$, the animals were given a maximum of $40 \mathrm{~mL}$ of milk, containing $40 \%$ milk fat, every $2 \mathrm{~h}$. Animals were obtained from INRA (St Gilles, France). Two animals (of six) died between 48 and $72 \mathrm{~h}$ of age in the control group. There was no mortality in the other groups. After 5 min of inhalation of chloroform, piglets were killed at the indicated times. The cerebellum, the cortex, and the hippocampus were dissected according to the stereotaxic atlas of Felix et al. (30), immediately frozen in liquid nitrogen, and stored at $-80^{\circ} \mathrm{C}$ for no longer than $2 \mathrm{wk}$.

\section{Experimental Methods}

Preparation of protein homogenates. For protein extraction, tissues were minced and placed in extraction buffer [TEX buffer $1 \times ; 60 \mathrm{mM}$ Tris-base (pH 6.8), 10\% glycerol, and 3\% SDS], and 5\% $\beta$-mercaptoethanol and the protease inhibitor Antagosan (Hoechst, France) were added just before use. Tissues were immediately homogenized in Ultra Turrax at maximum speed for $1 \mathrm{~min}$ on ice and centrifuged at 26,500 $\times$ $g$ for $15 \mathrm{~min}$. Supernatants were collected in a series of Eppendorf tubes and stored at $-20^{\circ} \mathrm{C}$ for no longer than $1 \mathrm{wk}$ before use. Protein concentrations were measured according to
Lowry et al. (31) using an ELISA plate reader (Argus 300; Packard, St. Cyr, France).

Equal amounts of protein were loaded on 13\% SDSpolyacrylamide gel with a $4 \%$ stacking polyacrylamide gel. Electrophoresis was performed in a buffer that contained 25 $\mathrm{mM}$ Tris ( $\mathrm{pH}$ 7.6), 0.1\% SDS, and $0.2 \mathrm{M}$ glycine. Proteins were subsequently transferred to Hybond $\mathrm{C}$ membranes (Amersham, Orsay, France) over 75 min using a buffer that contained $25 \mathrm{mM}$ Tris ( $\mathrm{pH}$ 7.6), 0.1\% SDS, $0.2 \mathrm{M}$ glycine, and $20 \%$ methanol. Blots were washed four times with TBST [20 $\mathrm{mM}$ Tris-base (pH 7.6), $12.5 \mathrm{mM} \mathrm{NaCl}$, and $0.5 \%$ Tween-20] and dipped in rouge Ponceau stain for $1 \mathrm{~min}$ to reveal the markers. The blots were washed four times in TBST buffer for 5 min each. Molecular weight markers were purchased from Sigma Chemical Co. (L'Isle d'Abeau, France).

Membranes were blocked for $1 \mathrm{~h}$ at room temperature in TBST buffer that contained 5\% milk powder and then incubated overnight at room temperature with the primary antibody. Specificity of anti-HSP27 (15), anti-HSP70 (16), and anti-HSP90 (17) has been previously established.

The blots were subsequently washed $5 \times 5$ min each in TBST buffer and 5\% skim milk powder that contained the secondary antibody at a 1:1000 dilution (anti-rabbit IgG peroxidase coupled from Sigma Chemical Co.). Protein bands were visualized by using diaminobenzidine (Sigma Chemical Co.) in $30 \mathrm{~mL}$ of buffer that contained $60 \mathrm{mM}$ Tris (pH 6.8), $0.2 \%$ hydrogen peroxide, and $200 \mu \mathrm{L}$ of $0.8 \% \mathrm{Ni} \mathrm{CI}_{2}$. Membranes were then washed in distilled water and dried at $37^{\circ} \mathrm{C}$ in an oven. Representative Western blots are shown in the figures.

For caspase-3, immunodetection was performed as described above with the following modifications: after blocking, membranes were incubated for $36 \mathrm{~h}$ at $4^{\circ} \mathrm{C}$ in TBST that contained 5\% skim milk and the caspase-3 primary antibody. After three washes, membranes were incubated for $1 \mathrm{~h}$ at room temperature in TBST that contained peroxidase-conjugated secondary antibody. After rinsing, membranes were incubated for $1 \mathrm{~min}$ in ECL + reagent (Amersham), and the specific binding was detected by exposing of the membrane to autoradiographic film (Amersham).

\section{Standardization and Statistical Analysis}

To check for equal protein loading of each lane, we examined the same membranes for $\beta$-actin protein (Sigma Chemical Co., ref. 9044). The secondary antibody was peroxidase coupled (Sigma Chemical Co.). Secondary antibodies were used at dilution of 1:1000 and were anti-rabbit with the exception of anti-mouse for HSP90 and $\beta$-actin. To compare densities, we scanned in membranes using a phosphor imager (Quantum Appligene, Illkirch, France). The density of each band of interest was expressed as a percentage of the $\beta$-actin band density detected in the same gel band. Statistical analysis was performed as follows: after global ANOVA, mean values were compared as indicated in the legends by a nonparametric analysis for variance (Kruskal-Wallis test). When significant, two-by-two comparisons were made according to Conover (32) for the highly significance multiple comparison test, with $p<$ 0.01 indicating significance. 


\section{RESULTS}

\section{Venous Oxygen Saturation}

Oxygen saturation did not vary in neonatal pigs and remained at $\sim 70 \%$. Oxygen saturation in the venous blood was unchanged after $1 \mathrm{~h}$ of hypoxia. However, hypoxia for $4 \mathrm{~h}$ reduced oxygen saturation to very low levels in animals that were maintained at both 20 and $37^{\circ} \mathrm{C}$. Return of oxygen saturation to baseline or control value was still incomplete after $4 \mathrm{~h}$ of recovery. Twenty hours after hypoxia, no difference in oxygen saturation was detected between control and hypoxic animals.

\section{Body Temperatures}

Decrease in body temperature was observed in animals that were maintained at room temperature after $4 \mathrm{~h}$ of hypoxia.

\section{Animals that Were Maintained at Room Temperature during Hypoxia}

Relative expression of HIF-1a in cerebellum, cortex, and hippocampus after hypoxia. As depicted in Fig. 1, detectable HIF- $1 \alpha$ expression was observed at birth. However, more than an 8 -fold increase was observed in the cerebellum and the cortex after 1 or $4 \mathrm{~h}$ of hypoxia followed by $4 \mathrm{~h}$ of recovery. High levels of expression were observed in both control and hypoxic animals until $72 \mathrm{~h}$. In the hippocampus, an increased level of HIF- $1 \alpha$ expression was observed after the increase in cerebellum or cortex, i.e. 4, 20, and $44 \mathrm{~h}$ after hypoxia.

Relative expression of HSP27 in cerebellum, cortex, and hippocampus after hypoxia. As shown in Fig. 2, low levels of HSP27 expression were observed in normoxic animals. In the cerebellum, an increase in expression was observed after 1 and $4 \mathrm{~h}$ of hypoxia, and these increases persisted after $4 \mathrm{~h}$ of recovery. In the cortex, the same change occurred and persisted after $20 \mathrm{~h}$ of recovery. In the hippocampus, an increase in HSP27 expression was observed after 1 and $4 \mathrm{~h}$ of hypoxia and after 4 of hypoxia followed by $4 \mathrm{~h}$ of recovery.

Relative expression of HSP70 and HSP90 in cerebellum, cortex, and hippocampus after hypoxia. As depicted in Fig. 3, no significant change in HSP70 and HSP90 levels was observed in the three brain regions after hypoxia, except for a significant decrease in HSP90 levels in the cortex of animals that were subjected to hypoxia for $4 \mathrm{~h}$ with $4 \mathrm{~h}$ of recovery .

Relative expression of neuronal NOS and HO-2 in cerebellum, cortex, and hippocampus after hypoxia. Shown in Fig. 4 is the neuronal NOS (nNOS) and HO-2 expression in the cerebellum, the cortex, and the hippocampus of the piglet brain. In the cerebellum, no significant increase in nNOS expression was observed. In the cortex, a significant difference of expression was observed only after $1 \mathrm{~h}$ of hypoxia. With the exception of $4 \mathrm{~h}$ of hypoxia, no difference was observed in the hippocampus between controls and animals that were subjected to hypoxia. No difference in the expression of HO-2 was detected between controls and animals that were subjected to hypoxia.
HIF $1 \alpha$
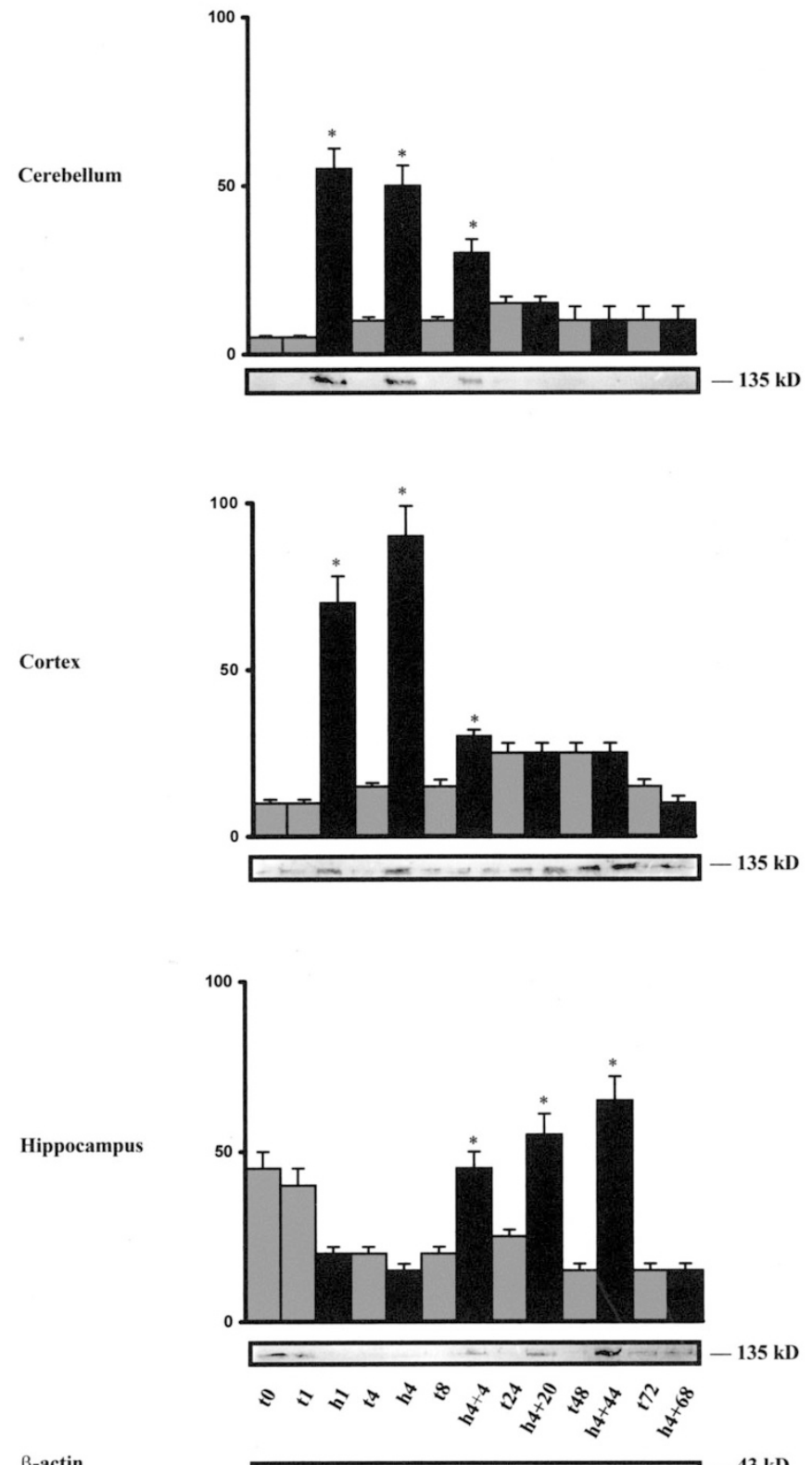

Figure 1. Relative expression of HIF- $1 \alpha$ in the cerebellum, cortex, and hippocampus after hypoxia of the piglet kept at room temperature. Lane t0 indicates newborn control; lanes $\mathrm{t} 1, \mathrm{~h} 1, \mathrm{t} 4, \mathrm{~h} 4, \mathrm{t} 8, \mathrm{~h} 4+4, \mathrm{t} 24, \mathrm{~h} 4+20 \mathrm{t} 48$, $\mathrm{h} 4+44$, and $\mathrm{t} 72, \mathrm{~h} 4+68$ indicate, respectively, control $1 \mathrm{~h}$, hypoxia $1 \mathrm{~h}$, control $4 \mathrm{~h}$, hypoxia $4 \mathrm{~h}$, control $8 \mathrm{~h}$, hypoxia $4 \mathrm{~h}$ followed by $4 \mathrm{~h}$ of recovery, control $24 \mathrm{~h}$, hypoxia $4 \mathrm{~h}+20 \mathrm{~h}$ recovery, control $48 \mathrm{~h}$, hypoxia $4 \mathrm{~h}+44 \mathrm{~h}$ recovery, control $72 \mathrm{~h}$ and hypoxia $4 \mathrm{~h}+68 \mathrm{~h}$ recovery. Light columns are for controls and dark columns for animals that were subjected to hypoxia. A total of $100 \mu \mathrm{g}$ of protein was loaded in each lane. The last representative membrane shows the level of $\beta$-actin in the cerebellum. Values are the mean \pm SEM of separate determinations; $n=4$. *Significantly different from the corresponding normoxic control $(p<0.001)$.

\section{Animals that Were Maintained at $37^{\circ} \mathrm{C}$ during Hypoxia}

Relative expression of HIF-1 $\alpha, \mathrm{HSP27}, \mathrm{HSP70}$, and $\mathrm{nNOS}$ in the cerebellum of animals that were maintained at $37^{\circ} \mathrm{C}$. As depicted in Fig. 5, HIF- $1 \alpha$ displayed maximum expression after 1 and $4 \mathrm{~h}$ of hypoxia. A similar observation was made for 


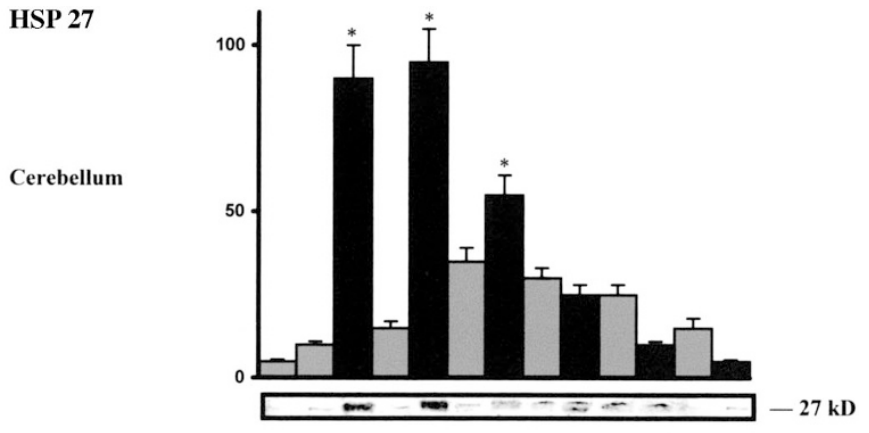

Cortex

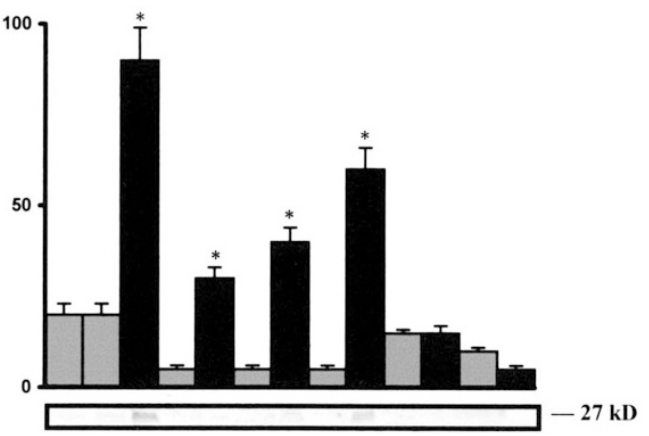

Hippocampus

$\beta$-actin

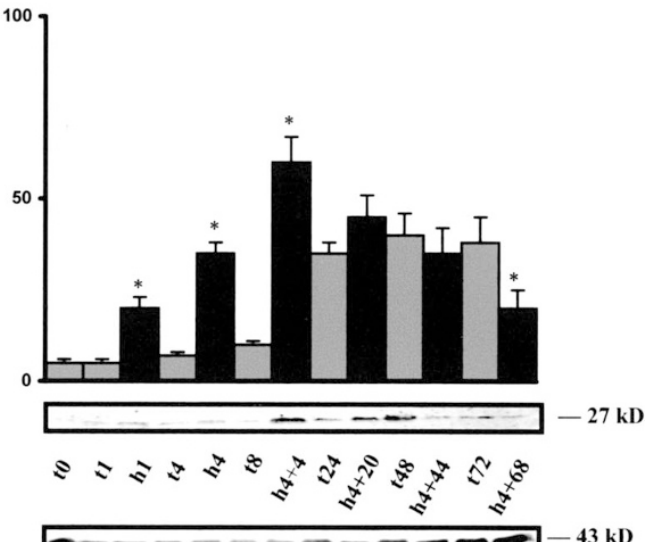

Figure 2. Relative expression of HSP27 in the cerebellum, cortex, and hippocampus after hypoxia of the piglet kept at room temperature. Lanes are as described in the legend of Fig. 1. A total of $100 \mu \mathrm{g}$ of protein was used for each lane. The level of $\beta$-actin in the cortex is shown in a representative membrane. Values are the mean \pm SEM of separate determinations; $n=4$. *Significantly different from the corresponding normoxic control $(p<0.001)$.

HSP27. These results parallel the observations presented in Figs. 1 and 2.

Identical results were observed for HSP70 and nNOS expression in the cortex of hypoxic animals that maintained at both temperatures. This is also true for HSP90 and HO-2 (data not shown).

Induction of Caspase 3 after Hypoxia. As shown in Fig. 6, increased levels of caspase 3 expression were observed in the cerebellum after $4 \mathrm{~h}$ of hypoxia followed by 4,20 , or $44 \mathrm{~h}$ of recovery. An important increase was also observed in the
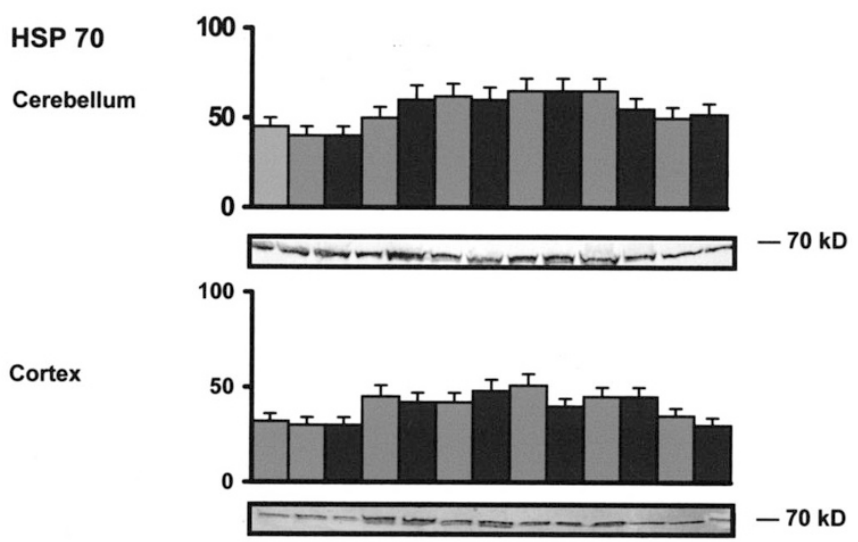

Hippocampus

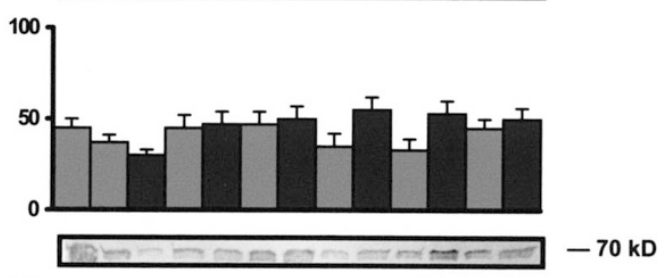

HSP 90

Cerebellum

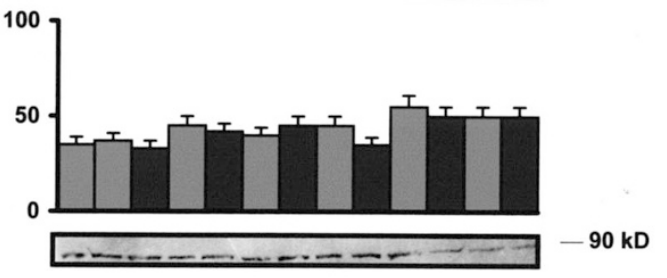

Cortex
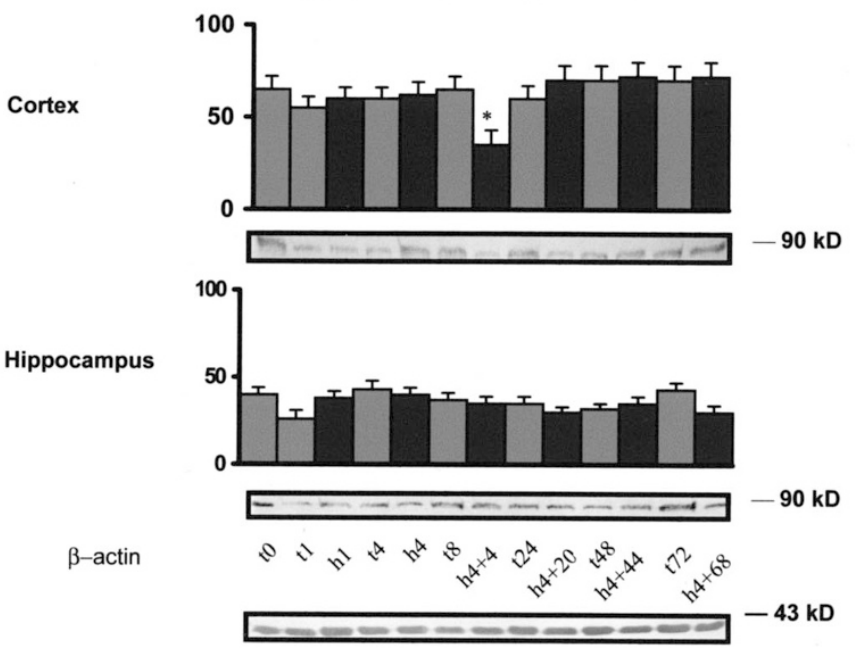

Figure 3. Relative expression of HSP70 and HSP90 in the cerebellum, cortex, and hippocampus after hypoxia of the piglet kept at room temperature. Lanes are as described in the legend of Fig. 1. A total of $100 \mu \mathrm{g}$ of protein was used for each lane. The level of $\beta$-actin in the cortex is shown in a representative membrane. Values are the mean \pm SEM of separate determinations; $n=4$. *Significantly different from the corresponding control $(p<0.01)$.

cortex after $4 \mathrm{~h}$ of hypoxia and $20 \mathrm{~h}$ of recovery. No significant differences were observed in the hippocampus (data not shown).

\section{DISCUSSION}

Hypoxia associated with reoxygenation or ischemia can cause extensive neurologic deficits in immature animals $(2,33-$ 35 ). Physiologic consequences of hypoxia have been well documented in mammals. Basically, after hypoxia, four differ- 


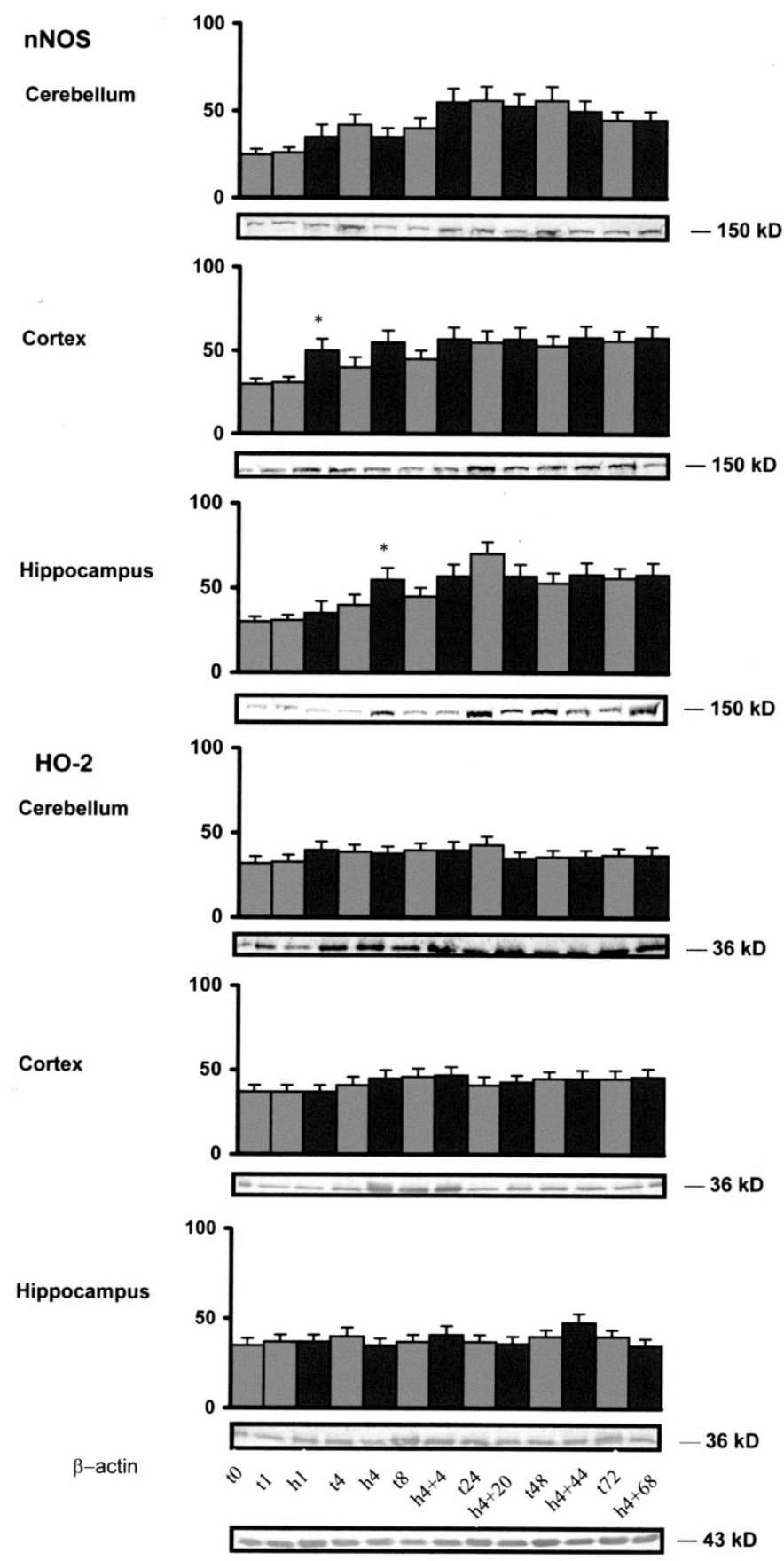

Figure 4. Relative expression of nNOS and HO-2 in the cerebellum, cortex, and hippocampus after hypoxia of the piglet kept at room temperature. Lanes are described in the legend of Fig. 1. A total of $100 \mu \mathrm{g}$ of protein was used for each lane. The level of $\beta$-actin in the cortex is shown in a representative membrane. Values are the mean \pm SEM of separate determinations; $n=4$. *Significantly different from the corresponding normoxic control $(p<0.01)$.

ent parameters are reduced: 1) body temperature, 2) heart rate, 3) respiratory rate, and 4) blood $\mathrm{pH}$.

Because of their small size and low metabolic rate, neonates are prone to hypothermia, resulting in a lowering of the metabolic rate. However, this decrease is associated with a protective effect (36). The reduction of heart rate, also known as the "diving reflex," is accompanied by shunting of blood flow from peripheral tissues to central organs (36). Such
HIF1 $\alpha$

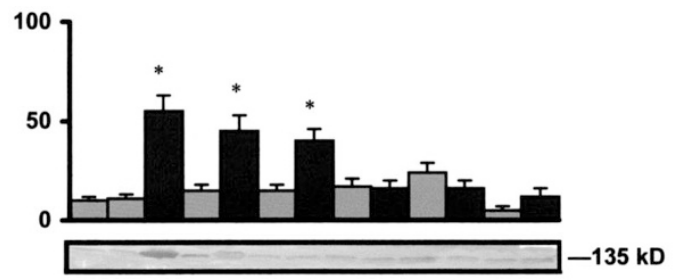

HSP 27

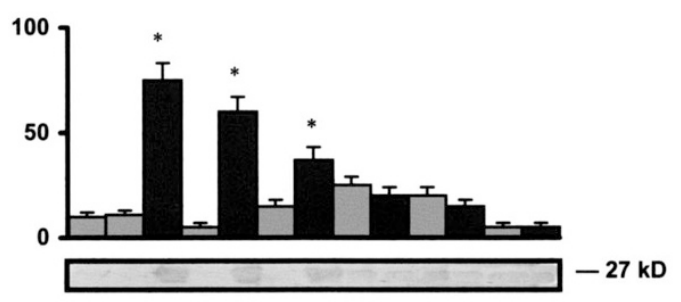

HSP 70

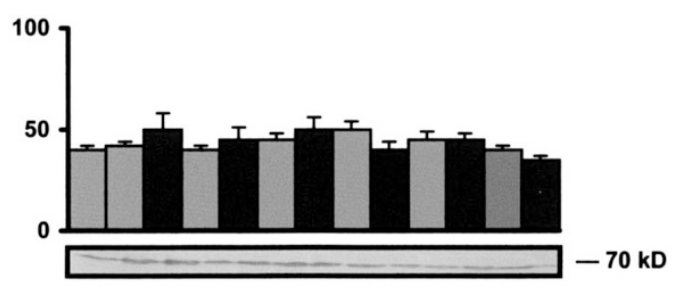

nNOS

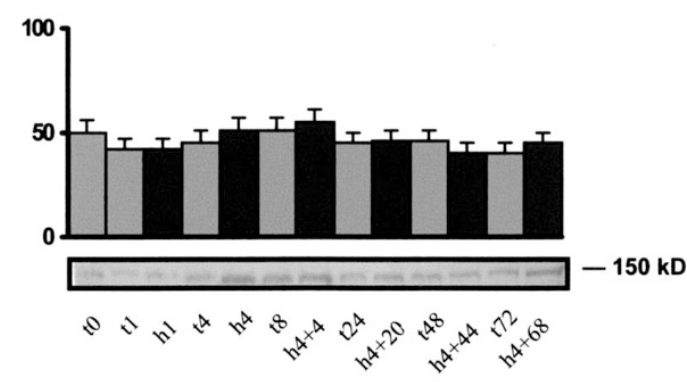

$\beta-$ actin

$-43 \mathrm{kD}$

Figure 5. Relative expression of HIF- $1 \alpha$, HSP27, HSP70, and nNOS in the cerebellum of piglets that were subjected to hypoxia and maintained at $37^{\circ} \mathrm{C}$. Lanes are as described in the legend of Fig. 1. A total of $100 \mu \mathrm{g}$ of protein was loaded in each lane. The last representative membrane shows the level of $\beta$-actin in the cerebellum. Values are the mean \pm SEM of separate determinations; $n=3$. *Significantly different from the corresponding normoxic control $(p<0.01)$

change is also associated with reduced glucose and increased blood lactate levels (37). The reduction of respiratory rate should be regarded as an immature feature of the respiratory network (38). The reduction of blood $\mathrm{pH}$ is associated with respiratory acidosis as a result of the inhibition of the overall enzymatic machinery (36).

Because of insufficient glycogen stores (39), immature animals have a reduced capacity for free radical detoxification (40) and therefore are unable to cope with stress. Moderate hypercapnia, which is observed after hypoxia, may be beneficial (41).

The observed effects are mediated through generation of free radicals, leading to cellular DNA alteration (35), which eventually causes apoptosis (42). It is known that HSP can protect against the damaging effects of hypoxia $(43,44)$ and free radicals, specifically HSP27 (11). The present study is the first 

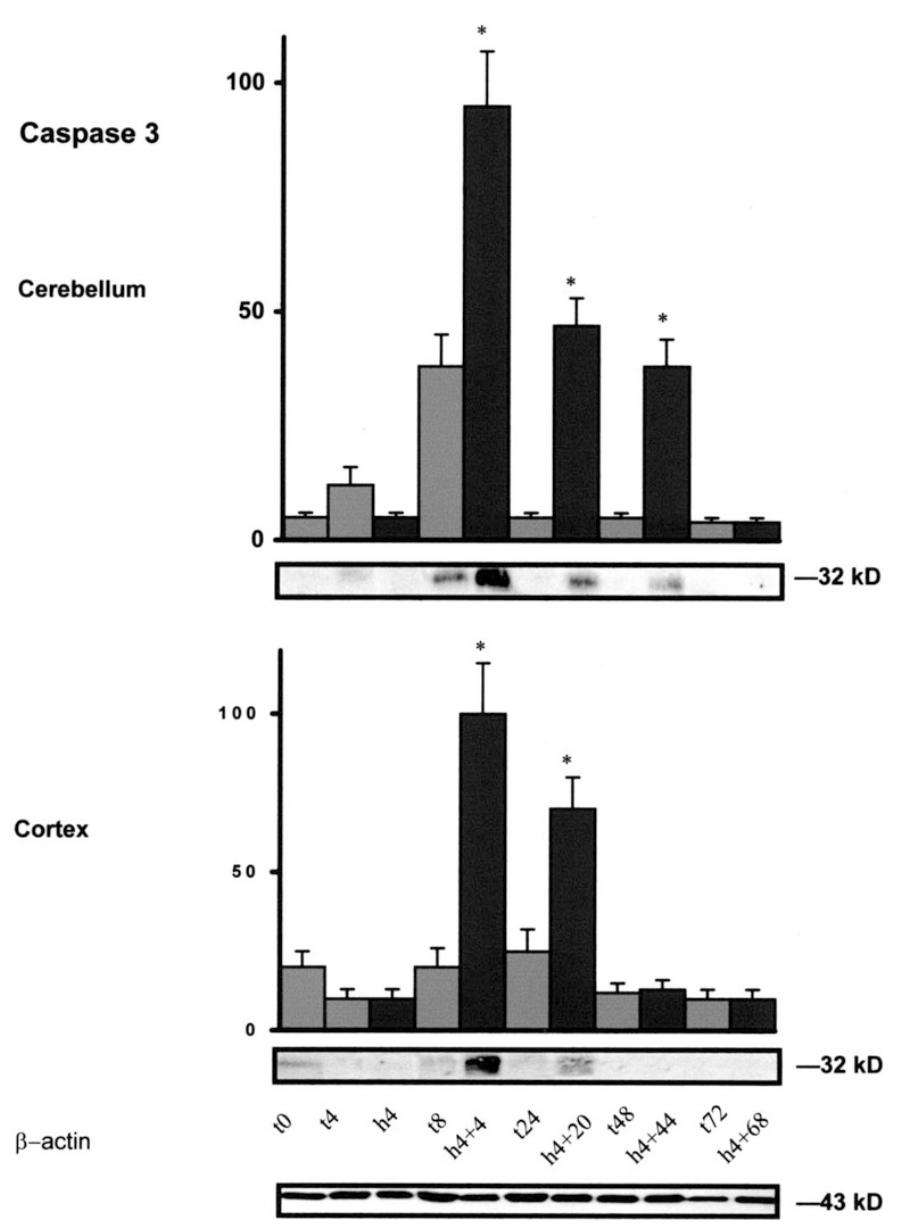

Figure 6. Relative expression of caspase 3 in the cerebellum and cortex after hypoxia of the piglet kept at room temperature. Lane t0 indicates newborn control; lanes t4, h4, t8, h4 + 4, t24, h4 + 20, t48, h4 + 44, t72, and h4 + 68 indicate, respectively, control $4 \mathrm{~h}$, hypoxia $4 \mathrm{~h}$, control $8 \mathrm{~h}$, hypoxia $4 \mathrm{~h}$ followed by $4 \mathrm{~h}$ recovery, control $24 \mathrm{~h}$, hypoxia $4 \mathrm{~h}$ followed by $20 \mathrm{~h}$ recovery, control $48 \mathrm{~h}$, hypoxia $4 \mathrm{~h}$ followed by $44 \mathrm{~h}$ recovery, control $72 \mathrm{~h}$ and hypoxia $4 \mathrm{~h}$ followed by $68 \mathrm{~h}$ recovery. An equal amount of protein was used as described in the legends of the other figures. Light columns are for controls, and dark are columns for animals that were subjected to hypoxia. The level of $\beta$-actin in the cortex is shown in a representative membrane. Values are the mean \pm SEM of separate determinations; $n=4$.

to investigate concomitant changes and possible relationships between HSP and adaptive molecules induced by hypoxia in the newborn during hypoxia.

Because cardiac frequency, arterial pressure, blood $\mathrm{CO}_{2}$, glucose, and $\mathrm{pH}$ after hypoxia have been documented in other studies (36), they were not determined in this study. The selected criterion for hypoxia was the oxygen saturation of $\mathrm{Hb}$. The hypoxic conditions $\left(4 \mathrm{~h}, 5 \% \mathrm{O}_{2}\right)$ resulted in a drastic decrease of the venous $\mathrm{Hb}$ saturation.

In the hippocampus, the cortex, and the cerebellum, a strong expression of HIF- $1 \alpha$ was detected very rapidly during hypoxia and slowly returned to baseline during the recovery period. Significant levels of expression at birth are not surprising, because HIF- $1 \alpha$ is already expressed in the fetus (45). Changes in the expression of HIF- $1 \alpha$ as a result of hypoxia are indicative of subsequent alterations of other downstream genes (24), particularly those involved in cellular energy metabolism, such as the glucose transporter (22). It should also be noted that, despite that HIF- $1 \alpha$ is quickly degraded (21), increased concentrations can last several hours after the hypoxic insult, thereby indicating an ongoing biosynthesis $(24,45)$.

As stated previously, hypoxia is associated with the depression of thermogenesis $(36,45)$. Under normal conditions, newborn animals are not artificially maintained at $37^{\circ} \mathrm{C}$ and cannot escape hypoxia-induced decrease in body temperature. However, human infants are maintained at $37^{\circ} \mathrm{C}$; thus, a complementary study on animals was performed. In the first series of experiments, animals were kept at room temperature; in the second series, their body temperature was maintained at $\sim 37^{\circ} \mathrm{C}$. In the first group, a significant decrease of temperature was observed after $4 \mathrm{~h}$ of hypoxia, whereas no change was observed in the second group. However, the percentage of venous $\mathrm{Hb}$ saturation indicated no difference between the two hypoxic groups.

One of the major findings of the present study is the discovery of increased levels of HSP27 expression in the cerebellum, cortex, and hippocampus during hypoxia and early recovery. An increase in HSP27 and HIF-1 $\alpha$ is observed in hypoxic animals with either a lower or a normal body temperature. We hypothesize that both the hyperthermia and the hypoxia increases HSP27. An interesting observation is the rapidity of the increased expression of both HIF-1 $\alpha$ and HSP27, which occur only $1 \mathrm{~h}$ after hypoxia. Because new protein synthesis is unlikely to occur in this time frame, other mechanisms may be operational (21). In the present study, no change in the expression of HSP70 or HSP90 after hypoxia was observed. This result is similar to findings presented in a previous study performed in the rat (43).

The specific response of HSP27 to hypoxia, independent of hyperthermia, is particularly interesting in muscle physiology. Small HSPs, such as HSP27, are strongly expressed in myoblasts and myocytes (46). A marked increase in HSP27 expression as a result of muscle hypoxia is associated with extensive muscular damage $(47,48)$. Increase in HSP27 expression can occur in glia and can tentatively be associated with cellular oxygen metabolism $(49,50)$ at the cytochrome level, resulting in apoptosis (50).

Another important aspect of the HSP27 response as observed in myoblast cell lines (51) is the translocation between nucleus and cytoplasm. However, the present observations should be complemented by future immunohistochemical studies, which would detect changes in subcellular localization.

The other proteins studied in the present investigation include nNOS and caspase 3 . NOS, specifically nNOS, is important because of its relationship to NMDA in the ischemiareperfusion model of brain injury. nNOS activation, through the generation of $\mathrm{NO}$, controls cerebral microcirculation during neural activity (52). Moreover, NMDA toxicity depends on the number of nNOS neurons and their specific expression (53). The importance of nNOS after hypoxia is further confirmed by the specific protection of these neurons after vascular stroke (54). This transient increase in nNOS expression suggests that a role for nNOS in blood flow regulation is limited to the initial phase of hypoxia. This increase in nNOS expression suggests the need for future study of other NOS isoforms, such as 
endothelial NOS, a major regulator of hemodynamics. Via the production of NO, NOS regulates HIF- $1 \alpha$ expression during hypoxia (55). NO produced by neuronal NOS also plays a critical role in cerebral capillary flow response to hypoxia (56).

Moreover, HSP70 (57) and HSP90 (26) can activate NOS, an enzyme that is associated with HO-2 (27). Studies of nNOS and HO-2 expression in the cerebellum, cortex, and hippocampus show relatively constant levels of nNOS, which is in agreement with the stable levels of HSP70 and HSP90 observed in the same brain regions. The apparent absence of global changes in expression of certain HSP isoforms or other stress proteins does not exclude modification at the subcellular level and therefore, warrants future immunocytologic investigations $(58,59)$.

Determination of caspase 3 expression shows that this protein is increased after hypoxia, which is in agreement with recently published observations (60). However, this is observed not only in the cortex but also in the cerebellum, and, more interesting, such an increase is even higher after $4 \mathrm{~h}, 1 \mathrm{~d}$, and even $2 \mathrm{~d}$ of recovery, indicating a delayed posthypoxic response $(33,36)$ in these regions. Very low caspase 3 activity was observed in the hippocampus (data not shown).

The present observations also show that an increase in specific HSP (HSP27) expression can still occur several hours after hypoxia, and this change has to be related to delayed protection of neurons $(33,42)$ that is necessary after NOS enzyme activation (61). Inhibition of nNOS and inducible NOS after hypoxia-ischemia results in long-term improvement of the rat brain (62). It has also been shown that introducing posthypoxic hyperbaric oxygenation can prevent brain injury induced by hypoxia-ischemia (63).

\section{CONCLUSION}

Our study reveals that the newborn piglet model can be used to evaluate the impact of hypoxia at the molecular level as demonstrated by other groups. The present piglet model can also be used for studying the effect of hypo- or hyperthermia associated with hypoxia and correlating the changes with behavioral outcome. Further characterization at the molecular and cellular level will provide credence to the usefulness of this model.

Acknowledgments. We are grateful to J. Lareynie and M. Lesage for technical assistance and to M. Herrouin for preparing the manuscript. Acknowledgments are also given to Air Liquide for the generous gift of the nitrogen used in this study.

\section{REFERENCES}

1. Nagdyman M, Komen W, Ko HK, Müller C, Obladen M 2001 Early biochemical indicators of hypoxia-ischemia encephalopathy after birth asphyxia. Pediatr Res 49:502-506

2. David JC, Grongnet JF 2000 Effect of hypoxia on DNA fragmentation in different brain regions of the newborn piglet. Mol Reprod Dev 57:153-158

3. Jiang ZD 1995 Long-term effect of perinatal and postnatal asphyxia on developing human auditory brainstem responses: peripheral hearing loss. Int J Pediatr Otorhinolaryngol 33:225-238

4. Jiang ZD, Brosi DM, Wilkinson AR 2001 Comparison of brainstem auditory evoked responses recorded at different presentation rates of chicks in term neonates after asphyxia. Acta Paediatr 90:1416-1420
5. Gadian DG, Aicardi J, Watkins KE, Poter DA, Mishkin M, Vargha Kadem F 2000 Developmental amnesia associated with early hypoxic-ischaemic injury. Brain 123:499-507

6. Dalman C, Thomas HV, Davis AS, Gentz J, Lewis G, Allebeck P 2001 Signs of asphyxia at birth and risk of schizophrenia. Population-based control study. $\mathrm{Br} J$ Psychiatry 170:403-408

7. Dixon G, Badawi M, Kurinczuk JJ, Keogh JM, Silburn SR, Zubrick SR, Stanley FJ 2002 Early developmental outcomes after newborn encephalopathy. Pediatrics 109:26-33

8. Viapiano MS, Mitridate de Novara AM, Fiszer de Plazas S, Bozzini CE 2001 Prolonged exposure to hypobaric hypoxia transiently reduces $\mathrm{GABA}_{\mathrm{A}}$ receptor number in mice cerebral cortex. Brain Res 894:31-36

9. Hsu L, Rockenstein E, Mallory M, Hashimoto M, Masliah E 2001 Altered expression of glutamate transporters under hypoxic conditions in vitro. J Neurosci Res 64:193202

10. Skoff RP, Bessert DA, Barks JD, Song D, Cerghet M, Silverstein FS 2001 Hypoxicischemic injury results in acute disruption of myelin gene expression and death of oligodendroglial precursors in neonatal mice. Int J Dev Neurosci 19:197-208

11. Arrigo AP, Landry J 1994 Expression and function of the low molecular weight heat shock proteins. In: Morimoto L and Georgopoulos C (eds) The Biology of Heat Shock Proteins and Molecular Chaperones. Cold Spring Harbor Laboratory, Cold Spring Harbor, pp 335-373

12. Kiang JG, Tsokos GC 1998 Heat shock proteins $70 \mathrm{kDa}$ : molecular biology, biochemistry and physiology. Pharmacol Ther 80:183-201

13. Csermely P, Schnaider T, Söti C, Prohaszka Z, Nardai G 1998 The 90 kDa molecular chaperone family: structure, function, and clinical applications. Pharmacol Ther 79:129-168

14. Hammerer-Lercher A, Mair J, Bonatti J, Watzka SB, Puschendorf B, Dirnhofer S 2001 Hypoxia induces heat shock protein expression in human coronary artery bypass grafts. Cardiovasc Res 50:115-124

15. David JC, Landry J, Grongnet JF 2001 Perinatal expression of heat-shock protein 27 in brain regions and nonneural tissues of the piglet. J Mol Neurosci 15:109-120

16. David JC, Tanguay RM, Grongnet JF 2001 Perinatal expression of HSC70 and HSP70 in neural and non neural tissues of the piglet. Brain Res Dev Brain Res 128:91-99

17. David JC, Grongnet JF 2001 Perinatal expression of heat-shock protein 90 in different regions of the brain and in non-neural tissues of the piglet. Biol Neonate 179:131-139

18. Kawana K, Miyamoto Y, Tanonaka K, Hanno Y, Yoshida H, Takahashi M, Takeo S 2000 Cytoprotective mechanism of HSP70 against Hypoxia/reoxygenation injury. J Mol Cell Cardiol 32:2229-2237

19. Lee JE, Yenari MA, Sun GH, Xu L, Emond MR, Cheng D, Steinberg GK, Giffard RG 2001 Differential neuroprotection from human heat-shock protein 70 overexpression in in vitro and in vivo models of ischemia and ischemia-like conditions. Exp Neurol 170:129-139

20. Wenger RH, Gassmann M 1997 Oxygen(es) and the hypoxia inducible factor-1. Biol Chem 378:609-616

21. Gassmann M, Wenger RH 1997 HIF-1, a mediator of the molecular response to hypoxia. News Physiol Sci 12:214-218

22. Chavez JC, Agani F, Pichiule A, LaManna JC 2000 Expression of hypoxia inducible factor- $1 \alpha$ in the brain of rats during chronic hypoxia. J Appl Physiol 89:1937-1942

23. Madan A, Varma S, Cohen HJ 2002 Developmental stage-specific expression of the alpha and beta subunits of HIF-1 protein in the mouse and human fetus. Mol Genet Metab 75:244-249

24. Bergeron M, Yu AY, Solway KE, Semenza GL, Sharp FR 1999 Induction of hypoxia inducible factor-1 and its target genes following focal ischemia in rat brain. Eur J Neurosci 11:4159-4170

25. Katschinski DM, Le L, Heinrich D, Wagner KF, Hofer T, Schindler SG, Wenger RH 2002 Heat induction of the unphosphorylated form of hypoxia inducible factor-1 alpha is dependent on heat-shock protein 90 activity. J Biol Chem 277:9262-9267

26. Garcia-Cardena G, Fan R, Shah V, Sorrentino R, Cirino G, Papapetropoulos A, Sessa WC 1998 Dynamic activation of endothelial nitric oxide synthase by HSP90. Nature 392:821-824

27. Van Ginneken C, Van Meir F, Sys S, Weyns A 2001 Developmental changes in hemeoxygenase- 2 and bNOS expression in enteric neurons in the pig duodenum. Auton Neurosci 91:16-25

28. Martin LJ, Brambrink AM, Lehmann C, Portera-Cailliau C, Koehler R, Rothstein J, Traytsman RJ 1997 Hypoxia-ischemia causes abnormalities in glutamate transporters and death of astroglia and neurons in newborn striatum. Ann Neurol 42:335-348

29. Ikari A, Nakano M, Kawano K, Suketa Y 2002 Up-regulation of sodium-dependent glucose transporter by interaction with heat shock protein 70. J Biol Chem 277:33338-33343

30. Felix B, Leger MF, Albe Fessard D, Marcilloux JC, Rampin O, Laplace JP 1999 Stereotaxic Atlas of the Pig Brain 49. Elsevier, New York, pp 1-137

31. Lowry OH, Rosebrough NJ, Farr AL, Randall RJ 1952 Protein measurement with the Folin phenol reagent. J Biol Chem 212:265-275

32. Conover WJ 1986 Practical Non-Parametric Statistics. Wiley, New York, pp 1-125

33. Namura S, Zhu J, Fink K, Endres M, Srinivasan A, Tomaselli KJ, Yuan J, Moskowitz MA 1998 Activation and cleavage of caspase-3 in apoptosis induced by experimental cerebral ischemia. J Neurosci 18:3659-3668

34. Taylor DL, Edwards AD, Mehmet H 1999 Oxidative metabolism, apoptosis and perinatal brain injury. Brain Pathol 9:93-117

35. Chen J, Jin K, Chen M, Pei W, Kawaguchi K, Greenberg DA, Simon RP 1997 Early detection of DNA strand breaks in the brain after transient focal ischemia: implications for the role of DNA damage in apoptosis and neural cell death. J Neurochem 69:232-245 
36. Singer D 1999 Review. Neonatal tolerance to hypoxia: a comparative physiological approach. Comp Biochem Physiol A Mol Integr Physiol 123:221-234

37. Lutz PC, Hochachka PW 1993 Hypoxia defence mechanisms: a comparison between diving reptiles and mammals. In: Hochachka PW, Lutz PC, Sick T, Rosenthal M, Van den Thillart T (eds) Surviving Hypoxia Mechanisms of Control and Adaptation. CRC Press, Boca Raton, pp 459-469

38. Ruggins MR 1991 Pathophysiology of apnea in preterm infants. Arch Dis Child $66: 70-73$

39. Diemer K 1968 Capillarisation and oxygen supply of the brain. In: Lübbers DW, Luft UC, Thews G, Witaleb E (eds) Oxygen Transport in Blood and Tissue. Thieme, Stuttgart, pp: $118-123$

40. Saugstadt OD 1990 Oxygen toxicity in the neonatal period. Acta Paediatr Scand. 79:881-892

41. Vannucci RC, Towfighi J, Brucklacher RM, Vannucci SJ 2001 Effect of extreme hypercapnia on hypoxic-ischemic brain damage in the immature rat. Pediatr Res 49:799-803

42. Chu D, Qiu J, Grafe M, Fabian R, Kent TA, Rassin D, Nesic O, Werrbach-Perez K, Perez-Polo R 2002 Delayed cell death signalling in traumatized central nervous system: hypoxia. Neurochem Res 27:97-106

43. Ikeda T, Abe K, Ota A, Ikenou T 1999 Heat shock protein 70 and heat shock cognate protein 70 messenger ribonucleic acid induction in the brains, hearts, and liver of neonatal rats after hypoxic stress. J Obstet Gynecol 180:457-481

44. Xia XY, Ikeda T, Ota A, Xia YX, Sameshima H, Ikenoue T, Toshimori K 1999 Hea shock protein 72 expression and microtubule-associated protein 2 disappearance afte hypoxia-ischemia in the developing rat brain. J Obstet Gynecol 180:1254-1260

45. Mortola JP 1999 How newborn mammals cope with hypoxia. Respir Physiol 116:95103

46. Fischer DA, Matten J, Reimann J, Bönnemann C, Schröder R 2002 Expression, localization and functional divergence of alphaB-crystallin and heat shock protein 27 in core myopathies and neurogenic atrophy. Acta Neuropathol (Berl) 104:297-304

47. Liu Y, Steinacker JM 2001 Changes in skeletal muscle heat shock proteins: pathological significance. Front Biosci 6:D12-D25

48. Thompson HS, Clarkson PM, Scordilis SP 2002 The repeated bout effect and hea shock proteins: intramuscular HSP27 and HSP70 expression following two bouts of eccentric exercise in humans. Acta Physiol Scand 174:47-56

49. Plumier JC, Amstrong JN, Wood NI, Babity JM, Hamilton TC, Hunter AJ, Robertson HA, Currie RW 1997 Differential expression of c-fos, HSP70 and HSP27 after photothrombotic injury in the rat brain. Mol Brain Res 45:239-246

50. Paul C, Manero F, Gonin S, Kretz-Remy C, Virot S, Arrigo AP 2002 HSP27 as a negative regulator of cytochrome c release. Mol Cell Biol 22:816-834
51. Sakamoto K, Urushidani T, Nagao T 1998 Translocation of HSP27 to cytoskeleton by repetitive hypoxia-reoxygenation in the rat myoblast cell line, $\mathrm{H} 9 \mathrm{C} 2$. Biochem Biophys Res Commun 251:576-579

52. Dawson VL, Kizushi VM, Huang PL, Snyder SH, Dawson TM 1996 Resistance to neurotoxicity in cortical cultures from neuronal nitric oxide synthase-deficient mice. J Neurosci 16:2479-2487

53. Samdani AF, Dawson TM, Dawson VL 1997 Nitric oxide synthase in models of focal ischemia. Stroke 28:1283-1288

54. Koh JY, Choi DW 1988 Cultured striatal neurons containing NADPH-diaphorase or acetylcholinesterase are selectively resistant to injury by NMDA receptors. Brain Res 446:374-378

55. Agani FH, Puchovicz M, Chavez JC, Pichiule P, LaManna J 2002 Role of nitric oxide in the regulation of HIF- $1 \alpha$ expression during hypoxia. Am J Physiol 283:C178C186

56. Hudetz AG, Shen H, Kampine JP 1998 Nitric Oxide from neuronal NOS plays critical role in cerebral capillary flow response to hypoxia. Am J Physiol 43:H982-H989

57. Bellmann K, Burkart V, Bruckhoff J, Kolb H, Landry J 2000 p38 dependent enhancement of cytokine induced nitric oxide synthase gene expression by heat shock protein 70. J Biol Chem 275:18172-18179

58. Rossiter JP, Anderson LL, Yang F, Cole GM 2002 Caspase-3 activation and caspase-like proteolytic activity in human perinatal hypoxic ischemic brain injury Acta Neuropathol (Berl) 103:66-73

59. Adachi M, Shoma O, Tsuneishi S, Takada S, Nakamura H 2001 Combination effect of systemic hypothermia and caspase inhibitor administration against hypoxicischemic brain damage in neonatal rats. Pediatr Res 50:590-595

60. Khurana P, Asraf QM, Misra OP, Delivora Papadopoulos M 2002 Effect of hypoxia on caspase- $3,-8$ and, -9 activity and expression in the cerebral cortex of the newborn piglets. Neurochem Res 27:931-938

61. Peeters-Scholte C, Koster J, Veldhuis W, van Den Tweel E, Zhu C, Kops N, Blomgren K, Bär D, Van Buul-Offers S, Hagberg H, Nicolay K, van Bel F, Groenendaal F 2002 Neuroprotection by selective nitric oxide synthase inhibition at 24 hours after perinatal hypoxia-ischemia. Stroke 33:2304-2310

62. van den Tweel ER, Peeters Scholte CM, van Bel F, Heijnen CJ, Groenendaal F 2002 Inhibition of nNOS and iNOS following hypoxia-ischemia improves long-term outcome but does not influence the inflammatory response in the neonatal rat. Dev Neurosci 24:389-395

63. Calvert JW, Yin W, Patel M, Badr A, Mychaskiw G, Parent AD, Zhang JH 2002 Hyperbaric oxygenation prevented brain injury induced by hypoxia-ischemia in the neonatal rat model. Brain Res 951:1-8 